Journal of English Language Teaching

UNNES

\title{
Syllabus design in Business English based on the needs of Economics students
}

\author{
Tiara Nove Ria ${ }^{\bowtie 1}$, Djamaludin Malik ${ }^{2}$
}

${ }^{1,2}$ Universitas Pandanaran, Indonesia

\begin{abstract}
Article Info
Abstract

Article History:

Received in 13

October 2020

Approved in 29

November 2020

Published in 30

November 2020

Keywords:Syllabus;

Business English;

Needs Analysis

Business English is one branch of English for Specific Purposes. In determining the abilities to be achieved in learning objectives, material selection, and learning methods in this course, the syllabus design must be tailored to the needs of students and it is better to combine with the real work situation. Therefore, a need analysis is essential to use for designing the syllabus However, the recent syllabus did not match students need so that the aim of this study was to conduct need analysis to develop the Business English syllabus design for Economics students. It was based on two situations, learning needs and target situation needs. The subjects were students, lecturer, graduates and employers. The instruments to collect the data in this study were questionnaire and interviews. This study used quantitative and qualitative method. The results showed that students mostly need speaking skills to be emphasized to learn, while mastering vocabularies was the weakness that the students need to improve. Moreover, they tended to have drilling as the learning method. While the most materials of English Business used in workplace was reading instruction related work and documents. Based on the findings of this study, it can be used for designing the new syllabus.
\end{abstract}

(C) 2020 Universitas Negeri Semarang

Correspondent Address:

B3 Building FBS Unnes

p-ISSN 2252-6706 | e-ISSN 2721-4532

Sekaran, Gunungpati, Semarang, 50229

E-mail: tiaranoveria@unpand.ac.id 


\section{INTRODUCTION}

English is a language that must be mastered by most people today. English language skills are seen to support self-development. In today's world of work, many companies have implemented English language skills to support their work. A study conducted by (Setiawan, 2014) stated that English is highly essential used in the world of work and this skill helps the workers enhance their career. Consequently, universities as places that produce people to compete in the world of work must provide English learning facilities. The Economics Faculty of Universitas Pandanaran seeks to produce graduates who can compete in the world of work. Therefore, the study program facilitates students by providing English courses, one of which is Business English. This course is given to students in semester 2. In order to achieve learning objectives, a course syllabus is compiled. The syllabus contains the course achievements, the course objective, the learning materials, the learning methods and time allocation.

In pre observation, the researcher observed by asking students about Business English learning and teaching process, then students gave information that was based on their experience. Some materials that were given by the lecturer were not tailored to their needs at work. The students' background was part time employers, so they had already known the use of English in their company. It happened because the syllabus and materials were design by the lecturer itself. It was designed only by putting the material that the lecturer felt was appropriate to give. Based on this case, the lecturer eager to find the solutions.

Business English is one branch of English for Specific Purposes (ESP). As stated in (Hutchinson, T., \& Waters, 1987), ESP is the way the learners learn English for the needs of specific fields. The use of English varies from one field to another. An Engineer needs the knowledge of English about their Engineering field, and it will be different in English used by the people who work in the Economic environment. The specific terms used are different to each other. It brings the nonnative to learn English for Specific Purposes. English for Specific Purposes (ESP) are subjects that are designed based on the specific needs related to the work or academic of students, and the subjects offer a description of the use of language in the discipline or job they serve (Basturkmen, 2010). So it is clear that English is only designed for material specifically to suit the learner's scientific background. Business English is a branch of ESP apart from others such as English for Police, English for nurses, Legal English and so on (Richards, 2001). In this case, the students of Economics need to focus their learning in Business English as their knowledge to be ready in their future work.

According to (Basturkmen, 2010), a need analysis can be the way to develop what the need to teach and learn English for Specific Purposes. Need analysis was an essential component to design and develop the course. This is the chance for the lecturer to do a need analysis so the course can meet the students' goals.

Determining learners' needs in learning English is called needs analysis or needs assessment (Hossain, 2013). Needs analysis is the process of gathering information and improving language planning. As concluded by Alfehaid in his dissertation, the findings from the needs analysis are analyzed to propose improvements so that academic needs and workplace language can be integrated, thereby increasing future student achievement (Alfehaid, 2011). According to Hutchinson and Waters in (Diana \& Mansur, 2018), need analysis is divided into two, target situation needs and learning needs. The target situation needs can specify goals and objectives. It is like a compass for learners to know the road to their goals. On the other side, the learning needs specify the learners' situations (background, motivation, skills, strategies).

The syllabus design is the necessary process of planning the teaching, while needs analysis is the primary guide of the phases that are passed to design ( $\mathrm{Li}, 2014)$. Therefore, in the process of syllabus development planning, a needs analysis is carried out. According to (Chunling, 2015), needs analysis is the first thing to do in designing a Business English course. The things that are needed in developing syllabus design based on the needs analysis are knowing the learning needs, learning objectives, final abilities to be achieved, determining the learning method and the suitable time that should be allocate in each meeting.

In several studies, it was stated that to design material and syllabus was essential to conduct need analysis. According to (Diana \& Mansur, 2018), in her study, the design of the syllabus for ICT students was based on the lecturer's perception so that the syllabus did not meet the students' need. Then she conducted the need analysis to find the appropriate materials needed by ICT students. In line with Diana \& Mansur's research, (Aflah \& Rahmani, 2018) stated that needs analysis plays a 
vital role in teaching and learning students majoring in nutrition because it would improve the learning process. Students, lecturers, learning objectives, learning materials, and learning methods would be well connected because they know the learning needs. Another study by (Remache \& Ibrahim, 2018), suggested that English teachers conducted a similar study using needs analysis for designing better syllabus. The result of the study was syllabus design that suits with students' needs, wants, desires and expectations of the students. According to (Dzięcioł-Pędich, 2014) her research presented possible suggestions for Business English course design and stressed the importance of needs analysis for developing an ESP syllabus in the context of Polish education. From several kind of research that have been conducted, it concerns only on the students situation. It has not been investigated in the real work situation. The employers and the graduates who already face the real situation can be the external factors besides students who know and feel the needs based on their own. The employers and graduates can give the information of the needs which can be verified. Hence, the researcher wants to conduct the research of need analysis to get the best design of syllabus that is taken from two situations so that the students of Economics at Universitas Pandanaran Central Java Indonesia reach the goal of studying Business English Course.

\section{METHODS}

This study's participants were 52 students in the second semester of Economics Faculty of Universitas Pandanaran, an English lecturer who teaches in this institution, 50 graduates, and two employers from hospitality and Manufacture companies. The students consist of 35 females and 17 males that had already taken General English in the previous semester. The students' age was between 19 to 25 years old. The English lecturer (EL) had been working in Universitas Pandanaran for three years. Graduates who work in various companies. The employers' position was a Sales Manager (SM) of Hotel Horison Semarang and a Manager HRD (H) of Holi Karya Sakti Semarang.

In need analysis, there are some instruments that can be used to conduct a need analysis such as interviews, questionnaires, or observation (Basturkmen, 2010). In this study, the instruments consist of questionnaires and interviews. The questionnaires were distributed to 52 students and 50 graduates of Economics Faculty. The students were the $2^{\text {nd }}$ semester who took Business English Course and the graduates of Economics Faculty were taken from the convenience sampling technique. At the same time, the interview was conducted to an English lecturer who teaches in this institution, graduates and employers. The interview employed semi-structured interview.

The questionnaire consists of several questions, including the students' background, the students' perception of learning Business English, the students' lacks and wants in learning English, students' preference of learning method during the class, and students' need for time allocation. While the graduates' questionnaire includes the importance of English language, the frequency of English skills used in the workplace, and the materials used in the workplace. The types of questions in this questionnaire are closed questions and multiple-choice questions. The interview employed semi-structured interviews that were asked to the lecturers, the graduates, and employers.

The procedures of data collections were from questionnaires submitted by students and graduates then classifying the results. Then the interview that was conducted to the English lecturer, graduates and employers to get deeper information based on the questionnaire.

The qualitative and quantitative methods were used to analyze the result after the researcher collected the data. The questionnaires were tabulated using quantitative by writing the percentage then it was displayed to words for showing the result and the last the researcher drawn the conclusion. The interview was analyzed qualitatively to interpret the result of the study objectives (Creswell, 2002). The semi-structured interview was conducted by the researcher to support the data from questionnaires that were distributed to the students and graduates.

\section{FINDINGS AND DISCUSSION}

The first sources are based on questionnaires of the students and semi-structured interviews with the lecturer. In the questionnaire, the first information was about the students' backgrounds. The students who participated in this study were 52 consists of 35 females and 17 males. They were 39 (75\%) students of Management and 13 (25\%) students of Accounting. The range of students' age was varied. They were from 19 to 30 . The 24 students in the age of 19-21, at the age of 22 to 24 , were 18 students, at 25 and above were 10 students.

Next was about their assessment self. It was conducted in the questionnaire questions, which showed the students' level of English proficiency. The level ranged from low (6), fair (38), good (7), 
and very good (1). It indicates that the students were mostly in the average level of English. These students' backgrounds must be the lecturer's concern to know how to treat the students. The students' age was majority mature. It will influence the way they learn. As stated by (Palea \& Bostine-Bratu, 2015), age cannot be used as a benchmark between adolescents or adults in foreign language learning. Learning achievement depends on how the lecturer creates situations and motivates students to achieve what they are aiming for. It also applies to the level of English proficiency, that learning strategies are the main thing that lecturers must consider in improving students' English skills (Kunasaraphan, 2015).

The second information, the questions were about the students' perception of the Business English Course. There were three questions asked to the students for supporting the students' perception. They are (1) English language skills are needed for their future work, (2) Business English course is needed to be taught for students and (3) Business English course supports their English task at work. For the first question, there were using scales with range "Strongly Agree," "Agree," "Disagree," and "Strongly Disagree."

Table 1. English language skills are required for your future work

\begin{tabular}{ccc}
\hline Choices & Answer & Percentage \\
\hline Strongly Agree & 27 & $52 \%$ \\
Agree & 24 & $46 \%$ \\
Disagree & 1 & $2 \%$ \\
Strongly Disagree & - & - \\
\hline
\end{tabular}

Table 1 above shows the response from the participants. More than half of participants strongly agree $(52 \%)$ and agree $(46 \%)$ that English language skills are required for their future work. It is only $2 \%$ or one student said disagrees.

The second question also scales by the same range. The question about the participants' perception of the Business English Course, whether it was needed for the learners.

Table 2. Business English courses need to be given to students

\begin{tabular}{ccc}
\hline Choices & Answer & Percentage \\
\hline Strongly Agree & 30 & $58 \%$ \\
Agree & 22 & $42 \%$ \\
Disagree & - & - \\
Strongly Disagree & - & - \\
\hline
\end{tabular}

The response was $58 \%$ strongly agree, and $42 \%$ agree that Business English needs to be given to students. The next question was about the participants' perception of the Business English Course to support their future work.

Table 3. The Business English courses that are taught will support your future work

\begin{tabular}{ccc}
\hline Choices & Answer & Percentage \\
\hline Strongly Agree & 27 & $52 \%$ \\
Agree & 24 & $46 \%$ \\
Disagree & 1 & $2 \%$ \\
Strongly Disagree & - & - \\
\hline
\end{tabular}

$52 \%$ or 27 participants strongly agree with the perception that the Business English Course will support their future work. This result followed by $46 \%$ of participants agreeing with the perception and only $2 \%$ or one participant who disagrees with the perception.

The finding of the perception above indicates that students had already realized the importance of English skills and English Business for their future careers or work. They have 
positive perceptions and motivations in learning English Business. The English lecturer (EL) supports this finding. Based on the interview,

The EL said:

"....Mahasiswa perlu diajarkan kemampuan Bahasa Inggris Bisnis yaitu Bahasa Inggris yang memang khusus untuk menyiapkan mahasiswa di pekerjaannya nanti..."

The translation:

"...Students need to be taught Business English, specifically for prapring the students in their future workplaces..."

Based on the results above, it is in line with what was said by (Meenu \& Pandey, 2014) that speaking English is essential because it is in high demand in the workplace. Therefore, Business English courses need to be taught as a provision for students in their future workplace. The third information was the participants' lack and wants in English learning. The results of the data were shown in the table below:

Table 4. Students' difficulties in English Mastery

\begin{tabular}{ccc}
\hline Difficulties & Yes & No \\
\hline Has a Limited Vocabulary of English & $49(94 \%)$ & $3(6 \%)$ \\
Cannot Speak English Well & $40(77 \%)$ & $12(23 \%)$ \\
Difficult in Pronouncing English Words & $40(77 \%)$ & $12(23 \%)$ \\
Cannot Understand Conversation in English Well & $33(63 \%)$ & $19(37 \%)$ \\
Difficulty in Writing English Sentences & $28(54 \%)$ & $24(46 \%)$ \\
Difficult in Understanding English Texts & $24(46 \%)$ & $28(54 \%)$ \\
\hline
\end{tabular}

Based on the result above, it was shown that the most difficulty in English skills was in the limitation of vocabulary. There were $94 \%$ of participants, while only $3 \%$ showed that they did not have a limited vocabulary. The next result was the difficulties in speaking well. There were $77 \%$ of the students found difficulty speaking English, and 23\% of students stated that there were no difficulties in this skill. Following it, $77 \%$ of participants found that pronouncing English words was difficult. In percentage, $63 \%$ of participants had difficulties cannot understand English conversation well and found it challenging to write English sentences (54\%). The last rank was $46 \%$ of the participants had difficulties in understanding English text.

Table 5. Students wants in learning English Skill

\begin{tabular}{ccc}
\hline Reading & 25 & $48 \%$ \\
Writing & 35 & $67 \%$ \\
Listening & 30 & $62 \%$ \\
Speaking & 45 & $86 \%$ \\
\hline
\end{tabular}

Table 5 showed the result of students' want to learn English skills. The speaking skill was the most wanted to be learned. There are $86 \%$ of participants needs this skill. In the second position needs by the participants was writing, $67 \%$. Then, there were $62 \%$ wanted to learn to listen, and the last was reading, in which only $48 \%$ of students want to learn the reading skill. According to the lecturer, the students need all four English skills because it was English skills are interrelated with each other, so that all need to be learned.

It is in line with what the lecturer wants:

The EL said that

“...buat saya kemampuan berbicara harus diajarkan di urutan pertama karena memang tujuan dari perkuliahan ini, jadi tiap pertemuan harus wajib ngomong ..."

The translation:

"...speaking is the first sequence to learn, followed by listening then reading and finally writing..."

The above research results can be used as guidance for lecturers in teaching the Business English courses. Students' weaknesses and desires become a reference for lecturers in choosing English skills that will be emphasized in class. As stated by (Huh, 2006), teaching business English 
should meet the learners' lacks and wants. It must be balanced so that it can meet the needs of students.

The fourth information was about the students' preference for learning methods. Table 6 below showed the results.

Table 6. Learning methods that suitable

\begin{tabular}{ccc}
\hline Drilling & 38 & $73 \%$ \\
Games & 9 & $17 \%$ \\
Discussion & 20 & $38 \%$ \\
Role Play & 10 & $19 \%$ \\
Lecturing & 1 & $2 \%$ \\
\hline
\end{tabular}

There were $73 \%$ of participants agree to use drilling as the learning method during the course. The second rank was discussing methods in learning English Business (38\%). Then 19\% agree that role-playing was a suitable learning method. Following by gaming, 17\% of participants wanted to use this method, and the last was lecturing, only $3 \%$.

Based on the EL, she said:

"...untuk pembelajaran Bahasa Inggris Bisnis akan lebih mudah diserap oleh mahasiswa jika metode yang digunakan adalah drilling atau bermain peran, kadang juga dengan model diskusi atau berkelompok..."

Translation:

"...for learning Business English it will be more easily absorbed by students if the method used is drilling or role playing, sometimes also with discussion or group models..."

As stated by (Montero et al., 2017), learning strategy is an important step that supports students in achieving their learning. The lecturers' concern is to follow what learning strategies fit the class to achieve the students' learning goals. In line with Montero, (Fatmawati et al., 2018) stated that teaching and learning activities would help students achieve the learning objectives.

The fifth information was about the time allocation for the Business English course. The result showed the high motivation of students in learning Business English. More than half of students or $60 \%$ stated agree, and 29\% of students strongly agree that the time allocation of the Business English course should be added. So far, the Business English course's time allocation was only two credits points $\mathrm{x} 45$ minutes in the 2 nd semester. It indicates that they had a more profound desire to learn Business English. It is known that motivation is an essential factor in foreign language learning. Therefore, the lecturer needs to identify the students' motivation in learning (Tambunan \& Siregar, 2016).

The last information was about the skills use and materials use in the workplace. The data sources taken from the questionnaire spread to graduates and interview to get the more in-depth information to graduates and employers. The graduates work in various companies such as manufacture, hospitality industry, distributor, education fields, and finance. It can provide information on the use of English in various fields, and the information comes from employers who understand the duties of their staff.

The graduates consisted of 22 females and 28 males. They mostly work in Semarang and surrounding areas. While the employers were two males where the company is located in Semarang. The result of the questionnaires and interviews were presented below.

The first question was about the importance of English skills.

Table 7. The Importance of English skills

\begin{tabular}{ccc}
\hline & Total & $\%$ \\
\hline Strongly Agree & 28 & 56 \\
Agree & 19 & 38 \\
Disagree & 2 & 4 \\
Strongly Disagree & 1 & 2 \\
\hline
\end{tabular}


The data showed that graduates are mostly strongly agreed on the importance of English skills in the workplace (56\%), followed by $38 \%$ that agree that graduates have to master English skills. However, there were 4\% disagree, and 2\% strongly disagree with having English skills. It indicates that the graduates strongly agree that English skills were vital because they often used these skills in their workplace, while the graduates who disagree and strongly disagree because they did not use English frequently so that they did not master English.

As stated by the Manager HRD of Holi Karya (HR) about the importance of English in the workplace.

The HR said:

"....Bahasa Inggris harus bisa, bahasa Inggris menjadi dasarnya, apalagi jika bekerja di situasi yang lingkungannya berhubungan dengan pihak luar.."

Translation:

"....English is a must. English is the basis, especially if you work in a situation where the environment is related to foreign parties..."

Based on the data above, English skills are essential. English language skills are needed in the world of work, especially now that many companies are associated with foreign parties or even companies owned by foreigners. According to (Clement \& Murugavel, 2018), English is essential for requiring a job, and these skills can effectively support the employees' career. In line with (Khan, 2017) that English is the dominant language globally because of globalization, it is essential to understand English skills and how we use it to communicate.

The English skills often used in the workplace can be seen in the table below.

Table 8. The frequency of English skills used in the

\begin{tabular}{ccc}
\multicolumn{3}{c}{ workplace } \\
\hline & Total & $\%$ \\
\hline Speaking & 30 & 60 \\
Listening & 28 & 56 \\
Reading & 36 & 72 \\
Writing & 29 & 58 \\
\hline
\end{tabular}

The questionnaire results showed that reading and speaking were mostly used at work through writing, and listening skills were needed in supporting their works. It was supported by an interview with graduates (G1) who work in Fuel and Basic Chemical Distribution.

The G1 said:

"....Bahasa Inggris banyak bu dipakai, seperti mendengarkan dan membaca istilah-istilah yang digunakan di pekerjaan, jika di level tertentu seperti Manager harus komunikasi karena direkturdirekktur ada yang dari luar..."

Translation:

"...English is often used, such as listening and reading the terms used at work, if at a certain level, such as manager, they have to use their speaking skill because there are directors who are a foreigner..."

Compared to the students' results, the students' and lecture's preference for learning English skills was quite different from the real situation. The graduates' responses were based on the use of their work places. Though the learning process was based on student needs as stated by (Hutchinson, T., \& Waters, 1987), it must be combined with the real situation of target situations (Mahardika, 2014). The materials used in the workplace are listed below:

Table 9. The use of English in the workplace

\begin{tabular}{lcc}
\hline & Total & $\%$ \\
\hline verbal instructions related to work & 20 & 40 \\
written instructions related to work & 27 & 54
\end{tabular}




\begin{tabular}{lcc} 
business presentations & 17 & 34 \\
job interview & 12 & 24 \\
business letter & 14 & 28 \\
business email & 18 & 36 \\
Proposals (projects, plans, etc.) & 6 & 12 \\
Expression of opinions at business meetings & 11 & 22 \\
work-related literature & 16 & 32 \\
serving customers orally & 23 & 46 \\
Documents report (meetings / sales / finance, etc.) & 24 & 48 \\
business conversation over the phone & 17 & 34 \\
job application letter and personal data & 12 & 24 \\
negotiation & 14 & 28 \\
\hline
\end{tabular}

The results showed the activities in English used in the workplaces of the graduates. These findings can be the reference of the lecturer to choose material for the students in each meeting. Verbal instructions related to work, written instructions related to work, business presentations, job interview, business letter, business email, Proposals (projects, plans, etc.), Expression of opinions at business meetings, work-related literature, serving customers orally, documents report (meetings/sales/finance, Etc.), business conversation over the phone, job application letter and personal data, negotiation. The data above was supported by the interview from the Sales Manager of Horison Hotel and graduates who work in a manufacturing company.

The next interview came from the Sales Manager (SM). The SM gave information about the use of English at work.

The SM said:

"... di awal mendaftar pekerjaan saya mendaftar di perusahaan ini menggunakan surat lamaran dan wawancara dalam bahasa Inggris...kalau penggunaan bahasa Inggris sendiri di dalam pekerjaan seringnya digunakan dalam menulis surat atau email seperti guarantee dan confirmation letter karena saya di bagian reservasi, tapi di bagian lain seperti sales itu biasanya melakukan meeting dengan pelanggan dari luar negeri..."

Translation:

"....At the beginning of applying for this job, I was asked to use application letter and interview in English ... if the use of English at work is often used in writing letters or emails such as guarantees and confirmation letters because I am in the reservation section, but in the section others such as sales usually hold meetings with customers from abroad.."

Then the information from the graduate (G2) who worked in manufacturing company as purchasing staff.

G2 said:

"...pada bagian pekerjaan saya di purchasing, saya biasanya menggunakan bahasa Inggris itu untuk membaca dan menulis email, surat bisnis dan laporan penjualan. Pekerjaan lainnya yang kadang menggunakan bahasa Inggris itu melayani complain dari customer, kadang lewat email atau lewat telepon jika memang dari customer menelepon..."

Translation:

"...In my part of the job at purchasing, I usually use English to read and write emails, business letters and sales reports. Other jobs that sometimes use English serve complaints from customers, sometimes via email or by phone if the customer calls ..."

The course objective can be the guidance of the lecturer to decide the topic that will be taught to students. As what (Remache \& Ibrahim, 2018) concluded in his study, that this was an opportunity for the lecturer to design better materials that meet the students' language need. 


\section{CONCLUSION}

Based on the result, the lecturer should concern all English skills, explicitly speaking and listening, that students mostly need to learn. However, the skill of writing and reading should be emphasized too in order to achieve the target needs. Students' wants and lacks in mastering English language skills are the central guides for the lecturer in motivating students to achieve learning goals. Also, the learning methods have to suit the students' needs to motivate them to acquire their language skills. The last is the time that should be allocate based on the needs of students in learning. The graduates' information about the language activity that often used can be the guidance for the lecturer to design a syllabus of Business English course that fits with the students' and targets' needs. For further research, this need analysis is essential for the lecturer in designing the syllabus based on students' needs in another ESP field. The combination sources from the learning and the target needs can be a good overview for improvement at ESP class.

\section{ACKNOWLEDGEMENT}

The authors would like to express special thanks for Directorate of Research and Community Service (DRPM) Kemenristekdikti who has supported the funding of this research with the scheme of Hibah Penelitian Dosen Pemula in the 2020 budget hence the research can be completed well.

\section{REFERENCES}

Aflah, M. N., \& Rahmani, E. F. (2018). Analisa Kebutuhan (Need Analysis) Mata Kuliah Bahasa Inggris untuk Mahasiswa Kejuruan. Jurnal Pendidikan Bahasa, 7(1), 77-89. https://doi.org/http://dx.doi.org/10.31571/bahasa.v7i1.828

Alfehaid, A. F. T. (2011). Developing an ESP Curriculum for Students of Health Sciences Through Needs Analysis and Course Evaluation in Saudi Arabia. In Unpublished Doctoral Thesis (Issue January). University of Leicester, Leicester, United Kingdom.

Basturkmen, H. (2010). Developing Courses in English for Specific Purposes. London: Palgrave Macmillan.

Chunling, G. (2015). Need Analysis and Curriculum Design in Business English. Studies in English Language Teaching, 3(2), 146. https://doi.org/10.22158/selt.v3n2p146

Clement, A., \& Murugavel, T. (2018). English for the Workplace: The Importance of English Language Skills for Effective Performance. The English Classroom, 20(1), 41-50.

Creswell, J. W. (2002). Educational Research Planning, Conducting and Evaluating Quantitative and Qualitative Research (4th ed.). Boston, US: Pearson Education,Inc.

Diana, S., \& Mansur, M. (2018). Need Analysis on English Teaching Materials for Ict Students. ETERNAL (English, Teaching, Learning, and Research Journal), 4(2), 209. https://doi.org/10.24252/eternal.v42.2018.a6

Dzięcioł-Pędich, A. (2014). Business English in the eyes of economics and management students at the University of Białystok. Studies in Logic, Grammar and Rhetoric, 38(51), 83-102. https://doi.org/10.2478/slgr-2014-0033

Fatmawati, Gani, S. A., \& Samad, I. A. (2018). Techniques for ESP Students in Teaching English. English Education Journal, 9(4), 513-526.

Hossain, J. (2013). ESP Needs Analysis for Engineering Students: A Learner Centered Approach. Journal of Presidency University, 2(2), 16-26.

Huh, S. (2006). A task-based needs analysis for a Business English course. Second Language Studies, $24(2), 1-64$.

Hutchinson, T., \& Waters, A. (1987). English for specific purposes. Cambridge: Cambridge University Press.

Khan, P. . B. (2017). Review Article: Impact Of English For Better Employment. Research Journal of English Language and Literature (RJELAL), 5(1), 612-613.

Kunasaraphan, K. (2015). English Learning Strategy and Proficiency Level of the First Year Students. Procedia - Social and Behavioral Sciences, 197(February), 1853-1858. https://doi.org/10.1016/j.sbspro.2015.07.246

Li, J. (2014). Needs Analysis: An Effective Way in Business English Curriculum Design. Theory and Practice in Language Studies, 4(9), 1869-1874. https://doi.org/10.4304/tpls.4.9.1869-1874

Mahardika, A. . N. Y. M. (2014). The Need for Needs Analysis in Curriculum Development in ESP Course : a Reflection on Curriculum Development in Indonesia. Lingua Scientia, 6(2), 183-194. 
Meenu, P., \& Pandey, P. (2014). Better English for Better Employment Opportunities. International Journal of Multidisciplinary Approaches and Studies, Volume 1(August), 96-103.

Montero, C. R., Sierra, B., \& Arizmendiarrieta. (2017). The effectiveness of a learning strategies program for university students. Psicothema, 29(4), 527-532. https://doi.org/10.7334/psicothema2016.171

Palea, L.-L., \& Bostine-Bratu, S. (2015). Age and Its Influence on Second Language Acquisition. Revista Academiei Fortelor Terestre, 20(4), 428-432.

Remache, A., \& Ibrahim, M. K. (2018). Business English Syllabus Design: Putting Students Needs First. International Journal of English Language and Literature Studies, 7(4), 81-93. https://doi.org/10.18488/journal.23.2018.74.81.93

Richards, J. C. (2001). Curriculum Development in Language Teaching (1st ed.). Cambridge, UK: Cambridge University Press. https://doi.org/10.1080/0261976022000044872

Setiawan, D. (2014). Workplace English in Indonesia. Victoria University.

Tambunan, A. R. S., \& Siregar, T. M. (2016). Students' Motivation in Learning English Language (a Case Study of Electrical Engineering Department Students). The Journal of English Language Studies, 01(02), 63-70. https://doi.org/http://dx.doi.org/10.30870/jels.v1i2.956 